\title{
Pemodelan Kemiskinan Pada Kabupaten/Kota Di Provinsi Jawa Timur Tahun 2015 Dengan Pendekatan Model Regresi Spasial
}

\author{
Siti Munadhiroh ${ }^{(1)}$, Wara Pramesti ${ }^{(2)}$ \\ 1,2) Universitas PGRI Adi Buana Surabaya \\ Jl. Dukuh Menanggal XII Telp./Fax. (031) 822289873 Surabaya 60234 \\ e-mail: Chit.chitcit@gmail.com dan warapra@unipasby.ac.id
}

\begin{abstract}
ABSTRAK
Regresi merupakan suatu teknik statitik yang dapat digunakan untuk menggambarkan hubungan fungsional antara suatu variabel respon dengan satu atau lebih variabel prediktor. Pengembangan dari analisis regresi klasik yang dipengaruhi efek ruang atau lokasi disebut analisis regresi spasial. Tujuan dari penelitian ini adalah untuk memodelkan kemiskinan pada kabupaten/kota di Jawa Timur tahun 2015 dengan pendekatan regresi spasial. Pada tahun 2015 kemiskinan di jawa timur mengalami peningkatan dibandingkan pada tahun sebelumnya. Oleh karena itu perlu mengidentifikasi faktor-faktor yang berpengaruh terhadap kemiskinan. Variabel yang digunakan yaitu persentase penduduk miskin sebagai variabel respon dan variabel prediktor meliputi pendidikan yang ditamatkan terakhir SD (X1), angka partisipasi sekolah 7-12 tahun (X2), pekerja sektor informal (X3), tingkat pengangguran terbuka (X4), rumah tangga menggunakan dinding bambu (X5), dan rumah tangga pengguna sumber air minum tidak layak (X6). Hasil penelitian diperoleh model terbaik untuk memodelkan persentase penduduk miskin yaitu Spatial Error Model (SEM) dengan matriks pembobot spasial Queen Contiguity dan diperoleh nilai AIC sebesar 191,02 dan R2 sebesar 77,47\%. Faktor-faktor yang berpengaruh signifikan terhadap persentase penduduk miskin yaitu angka partisipasi sekolah (X2), pekerja sektor informal (X3), rumah tangga pengguna sumber air minum tidak layak (X6) dan terdapat dependensi error pada lokasi satu dengan lokasi lainnya.
\end{abstract}

Kata kunci : Kemiskinan, Regresi, Spatial Error Model, Queen Contiguity.

\begin{abstract}
Regression is a technique that can be used for response variables with one or more predictor variables. The purpose of this study is to model poverty in districts / cities in East Java 2015 with a spatial regression approach. In 2015, poverty in East Java has increased compared to the previous year. Therefore it is necessary to identify the factors that affect poverty. The variables used are the percentage of poor population as the response variable and the predictor variables include last elementary school education (XI), school participation rate 7-12 years (X2), informal sector workers (X3), open unemployment rate (X4), household using bamboo walls (X5), and household users of inadequate drinking water sources (X6). The result of this research is the best model to model the percentage of poor people is Spatial Error Model (SEM) with spatial weighting matrix Queen Contiguity and obtained AIC value 191,02 and R2 equal to 77,47\%. Factors that have significant effect on the percentage of the poor are school enrollment (X2), informal sector workers (X3), household users of inadequate drinking water sources (X6) and there is an error dependency on one location to another.
\end{abstract}

Keywords : Poverty, Regression, Spatial Error Model, Queen Contiguity.

\section{PENDAHULUAN}

Analisis regresi merupakan metode analisis yang dapat digunakan untuk menganalisis data dan pengembangan dari analisis regresi klasik yang memungkinkan untuk mendapatkan informasi yang dipengaruhi efek ruang atau lokasi yaitu regresi spasial. regresi spasial merupakan salah satu metode statistik yang digunakan untuk memodelkan suatu permasalahan yang dipengaruhi oleh beberapa faktor tertentu dengan memperhatikan efek lokasi

Siti Munadhiroh 1, Wara Pramesti ${ }^{2}$ / J Statistika Vol.11, No.2, (2018) 
atau tempat (Anselin, 1988). Analisis regresi spasial dapat dibedakan menjadi dua pendekatan yaitu dengan pendekatan titik dan pendekatan area. Pada analisis regresi spasial dilakukan dengan menambahkan matriks pembobot spasial . Pembobot adalah unsur penting dalam menggambarkan kedekatan area yang ditentukan berdasarkan informasi atau kedekatan antara suatu area dengan area lain (neigborhood). Dalam penelitian ini pendekatan yang digunakan yaitu pendekatan area yang merupakan metode dengan menggunakan persinggungan antar lokasi yang berdekatan. Menurut LeSage (2009) terdapat beberapa pemodelan spasial dengan pendekatan area diantaranya adalah Spatial Autoregressive Model (SAR), Spatial Error Model (SEM), dan Spatial Autoregressive Moving Average (SARMA).

Kemiskinan merupakan masalah yang kompleks dan tidak sederhana penanganannya. Penduduk miskin merupakan penduduk yang memiliki rata-rata pengeluaran per kapita perbulan dibawah garis kemiskinan. Garis kemiskinan adalah suatu garis yang menunjukkan nilai pengeluaran makanan per orang untuk memenuhi kebutuhan dasar 2100 kkal per hari ditambah dengan pengeluaran non makanan selama satu bulan (BPS, 2015). Salah satu provinsi di Indonesia yang memiliki penduduk miskin terbanyak adalah Jawa Timur. Jumlah penduduk miskin di Jawa Timur pada Maret 2015 dibandingkan September 2014 naik sebesar 0,06 persen dari 12,28 persen (September 2014) menjadi 12,34 persen (Maret 2015). Salah satu upaya yang dapat dilakukan untuk menekan penduduk miskin adalah dengan mengidentifikasi faktor-faktor yang berpengaruh terhadap kemiskinan pada Kabupaten/Kota Provinsi Jawa Timur. Salah satu metode statistik yang digunakan yaitu analisis regresi. Namun metode regresi klasik tidak mampu mempertimbangkan aspek lokasi. Karena kemiskinan suatu wilayah dipengaruhi oleh kemiskinan di wilayah sekitar. Hal ini berdasarkan hukum pertama tentang geografis oleh W Tobler dalam Anselin 1988 yang menyatakan "Everything is related to everything else, but near thing are more related than distant thing". Oleh karena itu, digunakan pengembangan dari analisis regresi klasik, yaitu analisis spasial.

Penelitian terkait analisis spasial, salah satunya dilakukan oleh Rahmawati, dkk (2015) yang menyimpulkan bahwa terdapat hubungan signifikan pengangguran mempengaruhi jumlah penduduk miskin dengan menggunakan spasial error model. Tujuan yang ingin dicapai dalam penelitian ini yaitu ingin mengetahui pemodelan kemiskinan pada kabupaten/kota di Jawa Timur tahun 2015 dengan pendekatan regresi spasial. Dalam penelitian ini, permasalahan dibatasi dengan digunakan uji Moran's I pada uji fek spasial dan matriks pembobot spasial yang digunakan adalah Queen Contiguity (persinggungan sisi-sudut).

\section{METODE PENELITIAN}

Data yang digunakan dalam penelitian ini berupa data sekunder yang diperoleh dari Badan Pusat Statistik Jawa Timur pada tahun 2015. Wilayah yang digunakan dalam penelitian adalah kabupaten/kota yang ada di Jawa Timur yang terdiri dari 38 kabupaten/kota.

Variabel yang digunakan sebanyak tujuh variabel yang terdiri dari satu variabel respon yaitu persentase penduduk miskin (Y) dan enam variabel prediktor yaitu pendidikan yang ditamatkan SD $\left(\mathrm{X}_{1}\right)$, Angka Partisipasi Sekolah (APS) 7-12 tahun $\left(\mathrm{X}_{2}\right)$, pekerja sektor informal $\left(\mathrm{X}_{3}\right)$, Tingkat Penganggguran Terbuka (TPT) $\left(\mathrm{X}_{4}\right)$, rumah tangga menggunakan dinding bambu $\left(\mathrm{X}_{5}\right)$, dan rumah tangga pengguna sumber air minum tidak layak $\left(\mathrm{X}_{6}\right)$.

Metode Analisis yang digunakan yaitu pendekatan regresi spasial. Adapun langkahlangkah analisis sebagai berikut:

1. Memetakan persentase penduduk miskin dan melakukan analisis deskriptif

2. Menguji multikolinieritas

3. Mendapatkan pendugaan dan pengujian parameter model regresi klasik

4. Memeriksa asumsi pada model regresi klasik

5. Menyusun matriks pembobot spasial

6. Menguji efek ketergantungan spasial yaitu uji dependensi dengan uji Moran's I dan menentukan model spasial dengan uji Lagrange Multiplier (LM)

7. Mendapatkan pendugaan dan pengujian parameter model regresi spasial

8. Memeriksa asumsi pada regresi spasial

9. Melakukan pemilihan model terbaik dengan membandingkan R2 dan AIC

10. Interpretasi model terbaik

11. Menarik kesimpulan

\section{HASIL DAN PEMBAHASAN}

\section{a. Analisis Deskriptif}

Analisis deskriptif digunakan untuk mengetahui karakteristik pola persebaran persentase kemiskinan pada tahun $2015 \mathrm{Kab} /$ Kota di Provinsi Jawa Timur yang dapat dilihat pada Gambar 1. Peta tematik membagi kabupaten/kota menjadi enam

Siti Munadhiroh ${ }^{1}$, Wara Pramesti ${ }^{2}$ / J Statistika Vol.11, No.2, (2018)

2 
kelompok sesuai dengan kriteria kemiskinan Badan Ketahanan Pangan (2017).

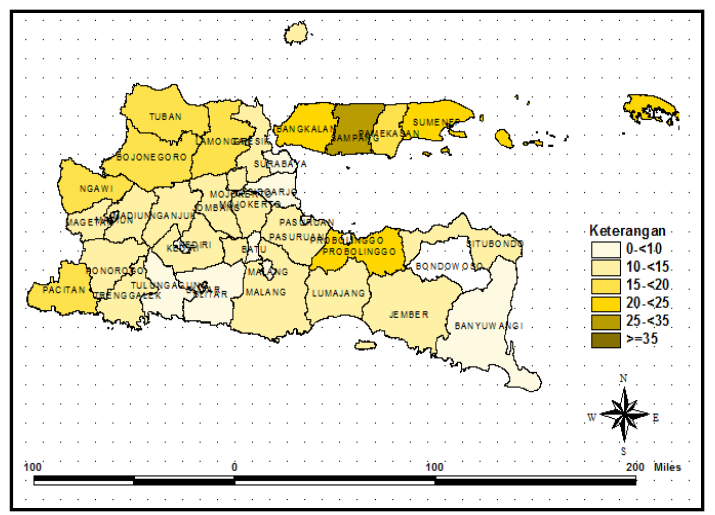

Gambar 1. Peta Persebaran Persentase Kemiskinan Kabupaten/Kota di Jawa Timur 2015

Gambar 1 menunjukkan pola persebaran persentase kemiskinan kabupaten dan kota di Jawa Timur terbagi menjadi enam kelompok dengan zona prioritas pertama $(>=35 \%)$ tidak terdapat kabupaten/kota yang masuk dalam kelompok ini. Zona prioritas kedua $(25-<35 \%)$ hanya terjadi pada kabupaten Sampang yang memiliki persentase kemiskinan tinggi sebesar $25,69 \%$. Zona prioritas ketiga $(20-<25 \%)$ terjadi di tiga kabupaten. Zona prioritas keempat $(15-<20 \%)$ terjadi di enam kabupaten. Zona prioritas kelima (10 - <15\%) terjadi di lima belas kabupaten. Sedangkan pada zona prioritas keenam $(0-<10 \%)$ terjadi di tiga belas kabupaten/kota dengan kota malang menduduki persentase kemiskinan paling rendah sebesar $4,60 \%$.

Sedangkan karakteristik dari masing-masing variabel penelitian dapat disajikan pada Tabel 1 yang menunjukkan bahwa variabel persentase penduduk miskin (Y) memiliki rata-rata sebesar $12,17 \%$ dengan persentase penduduk miskin tertinggi terdapat di kabupaten Sampang sebesar 25,69\% dan terendah terdapat di kota Malang sebesar 4,60\%. Variabel angka partisipasi sekolah 7-12 tahun $\left(\mathrm{X}_{2}\right)$ merupakan variabel dengan ratarata tertinggi sebesar $99,50 \%$ dengan persentase angka partisipasi sekolah 7-12 tahun tertinggi terdapat di tujuh belas kabupaten/kota yaitu kabupaten Pacitan, kabupaten Malang, kabupaten Bondowoso, kabupaten Pasuruan, kabupaten Sidoarjo, kabupaten Nganjuk, kabupaten Ngawi, kabupaten Bangkalan, kota Kediri, kota Blitar, kota Malang, kota Probolinggo, kota Pasuruan, kota Mojokerto, kota Madiun, kota Surabaya, dan kota Batu sebesar 100\% sedangkan yang terendah terdapat di kabupaten Pamekasan sebesar 97,30\%. Variabel tingkat pengangguran terbuka $\left(\mathrm{X}_{4}\right)$ merupakan variabel dengan rata-rata terendah sebesar 4,36\% dengan persentase tingkat pengangguran terbuka tertinggi terdapat di kota Kediri sebesar $8,46 \%$ dan terendah terdapat di kabupaten Pacitan sebesar 0,97\%.

Tabel 1. Statistika Deskriptif Variabel Penelitian

\begin{tabular}{|c|r|r|r|r|}
\hline Variabel & Mean & \multicolumn{1}{|c|}{ Min } & \multicolumn{1}{c|}{ Max } & \multicolumn{1}{c|}{$\begin{array}{c}\text { Std. } \\
\text { Dev }\end{array}$} \\
\hline $\mathrm{Y}$ & 12,17 & 4,60 & 25,69 & 5,03 \\
\hline $\mathrm{X}_{1}$ & 29,35 & 16,18 & 41,11 & 5,86 \\
\hline $\mathrm{X}_{2}$ & 99,50 & 97,30 & 100,00 & 0,69 \\
\hline $\mathrm{X}_{3}$ & 45,96 & 18,40 & 69,39 & 13,01 \\
\hline $\mathrm{X}_{4}$ & 4,36 & 0,97 & 8,46 & 1,73 \\
\hline $\mathrm{X}_{5}$ & 5,75 & 0,13 & 22,68 & 5,33 \\
\hline $\mathrm{X}_{6}$ & 24,01 & 2,79 & 48,91 & 11,60 \\
\hline
\end{tabular}

Pengujian multikolinieritas dilakukan untuk mengetahui apakah terjadi korelasi antar variabel bebas atau tidak. Dikatakan tidak terjadi multikolinieritas jika nilai $\mathrm{VIF}<10$.

Tabel 2. Uji Multikolinieritas

\begin{tabular}{|c|c|c|c|}
\hline Variabel & VIF & Variabel & VIF \\
\hline $\mathrm{X}_{1}$ & 2,1141 & $\mathrm{X}_{4}$ & 1,6536 \\
\hline $\mathrm{X}_{2}$ & 1,4575 & $\mathrm{X}_{5}$ & 1,8058 \\
\hline $\mathrm{X}_{3}$ & 2,5353 & $\mathrm{X}_{6}$ & 1,5063 \\
\hline
\end{tabular}

Tabel 2 dapat diketahui bahwa semua variabel bebas memiliki nilai VIF kurang dari 10. Sehingga dapat disimpulkan tidak terjadi korelasi antar variabel bebas.

\section{b. Analisis Regresi Berganda}

Sebelum dilakukan pemodelan dengan pendekatan spasial, terlebih dahulu dilakukan pemodelan regresi linier berganda dengan melakukan pengujian estimasi parameter baik secara serentak maupun parsial. Hasil pengujian estimasi parameter secara serentak dapat dilihat pada Tabel 3 sebagai berikut.

Tabel 3. Pengujian Parameter Serentak Regresi Linier Berganda

\begin{tabular}{|l|r|r|c|}
\hline Model & Regression & Residual & Total \\
\hline SS & 647,612 & 290,079 & 937,691 \\
\hline df & 6 & 31 & 37 \\
\hline MS & 107,935 & 9,357 & \\
\hline F $_{\text {hitung }}$ & 11,53 & & \\
\hline P-value & $9,196 \mathrm{e}-07$ & & \\
\hline
\end{tabular}

Keterangan: $\mathrm{F}_{(0,05 ; 6 ; 31)}=2,4094$

Berdasarkan Tabel 3 dapat diketahui bahwa diperoleh $\mathrm{F}_{\text {hitung }}$ sebesar 11,53 yang lebih besar dari $\mathrm{F}_{(0,05 ; 6 ; 31)}$ yang berarti tolak $\mathrm{H}_{0}$. Atau dapat dilihat 
dari $p$-value sebesar 9,196e-07 yang kurang dari $\alpha=5 \%$ yang berarti tolak $\mathrm{H}_{0}$. Jadi dapat disimpulkan bahwa terdapat pengaruh semua variabel independen secara bersama-sama terhadap variabel dependen yang signifikan. Selanjutnya dilakukan pengujian secara parsial yang dapat dilihat pada Tabel 4 sebagai berikut.

Tabel 4. Pengujian Parameter Serentak Regresi Linier Berganda

\begin{tabular}{|c|r|r|r|}
\hline Parameter & \multicolumn{1}{|c|}{ Estimasi } & \multicolumn{1}{c|}{$\mathbf{t}_{\text {hitung }}$} & P-value \\
\hline$\hat{\beta}_{0}$ & 150,0017 & 1,690 & 0,1010 \\
\hline$\hat{\beta}_{1}$ & $-0,0129$ & $-0,104$ & 0,9177 \\
\hline$\hat{\beta}_{2}$ & $-1,5053$ & $-1,701$ & 0,0989 \\
\hline$\hat{\beta}_{3}$ & 0,2649 & 4,303 & $0,0002 *$ \\
\hline$\hat{\beta}_{4}$ & $-0,0923$ & $-0,247$ & 0,8067 \\
\hline$\widehat{\beta}_{5}$ & 0,0192 & 0,151 & 0,8807 \\
\hline$\hat{\beta}_{6}$ & 0,0183 & 0,344 & 0,7329 \\
\hline \multicolumn{4}{|c|}{$\mathrm{R}^{2}=0,6906(69,06 \%)$} \\
\hline
\end{tabular}

Keterangan: $\mathrm{t}_{(0,025 ; 31)}=2,0395$

Berdasarkan Tabel 4 dapat diketahui bahwa hanya terdapat satu parameter yang berpengaruh signifikan yaitu $\widehat{\beta}_{3}$ yang memiliki nilai $t_{\text {hitung }}$ lebih besar dari $\mathrm{t}_{(0,025 ; 31)}$ yang berarti tolak $\mathrm{H}_{0}$. Atau dapat dilihat dari $p$-value yang kurang dari $\alpha=5 \%$ yang berarti tolak $\mathrm{H}_{0}$. Sehingga dapat disimpulkan bahwa variabel pekerja sektor informal $\left(\mathrm{X}_{3}\right)$ berpengaruh positif dan signifikan terhadap persentase penduduk miskin Koefesien determinasi $\left(\mathrm{R}^{2}\right)$ diperoleh sebesar $69,06 \%$. Hal tersebut menunjukkan bahwa variabel pendidikan yang ditamatkan terakhir $\mathrm{SD}\left(\mathrm{X}_{1}\right)$, angka partisipasi sekolah 7-12 tahun $\left(\mathrm{X}_{2}\right)$, pekerja sektor informal $\left(\mathrm{X}_{3}\right)$, tingkat pengangguran terbuka $\left(\mathrm{X}_{4}\right)$, Rumah Tangga menggunakan dinding bambu $\left(\mathrm{X}_{5}\right)$, dan Rumah tangga pengguna sumber air minum tidak layak $\left(\mathrm{X}_{6}\right)$ mampu menjelaskan sebesar $69,06 \%$ terhadap persentase penduduk miskin dan sisanya sebesar 30,94\% dijelaskan oleh variabel lain yang tidak terdapat dalam model. Dari Tabel 4 juga dapat diperoleh model persamaan sebagai berikut :

$$
\begin{aligned}
\hat{y}= & 150,0017-0,0129 X_{1}-1,5053 X_{2} \\
& 0,2649 X_{3}-0,0923 X_{4}+0,0192 X_{5} \\
& 0,0183 X_{6}
\end{aligned}
$$

\section{c. Uji Asumsi Regresi Linier Berganda}

Pengujian asumsi dalam regresi linier berganda yang terdiri dari tiga asumsi. Diperoleh hasil pengujian asumsi normalitas menggunakan uji Kolmogorov-Smirnov dengan nilai $p$-value sebesar 0,7345 lebih besar dari $\alpha=5 \%$ yang berarti asumsi residual berdistribusi normal terpenuhi. Pengujian heteroskedastisitas dengan uji Breusch-Pagan, diperoleh nilai $p$-value sebesar 0,2293 lebih besar dari $\alpha=5 \%$ yang berarti asumsi residual ragam homogen terpenuhi. Sedangkan pada pengujian autokorelasi menggunakan uji Durbin-Watson, diperoleh nilai $p$-value sebesar 0,000 kurang dari $\alpha=5 \%$ yang berarti asumsi residual independen terlanggar terjadi autokorelasi. Terlanggarnya asumsi independen terjadi karena adanya hubungan spasial di dalam peubah respon. Oleh karena itu dilakukan analisis regresi spasial.

\section{d. Matriks Pembobot Spasial}

Matriks pembobot spasial yang digunakan dalam penelitian ini yaitu pembobot spasial Queen Contiguity (persinggungan sisi dan sudut) dengan matriks W yang berukuran $38 \times 38$ sejumlah banyaknya kabupaten/kota di provinsi Jawa Timur. Dimana $\mathrm{W}_{\mathrm{ij}}=1$ untuk wilayah yang bersisian atau titik sudutnya bertemu dengan wilayah yang menjadi perhatian, sedangkan $\mathrm{W}_{\mathrm{ij}}=0$ untuk wilayah lainnya. Diperoleh matriks pembobot sebagai berikut:

$$
\begin{aligned}
& \text { Pacitan Ponorogo Batu } \\
& \mathbf{W}=\left[\begin{array}{ccccc}
0 & 1 & \ldots & \ldots & 0 \\
1 & 0 & \cdots & \cdots & 0 \\
\vdots & \vdots & \vdots & \ddots & \vdots \\
0 & 0 & \cdots & \cdots & 0 \\
0 & 0 & \cdots & \cdots & 0
\end{array}\right] \begin{array}{c}
\text { Pacitan } \\
\text { Surabayo } \\
\text { Batu }
\end{array}
\end{aligned}
$$

\section{e. Uji Dependensi Spasial}

Uji dependensi spasial yang digunakan yaitu uji Moran's I untuk mengetahui ada atau tidaknya pengaruh spasial terhadap model.

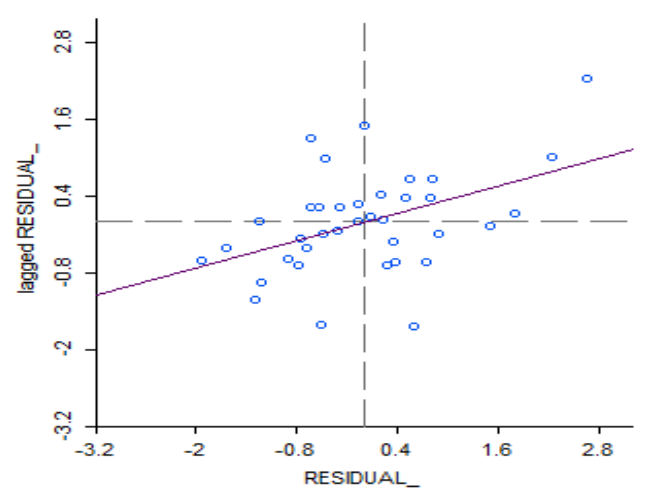

Gambar 2. Scattermoran's I

Siti Munadhiroh 1, Wara Pramesti ${ }^{2}$ / J Statistika Vol.11, No.2, (2018) 
Dari hasil pengujian diperoleh nilai Moran's I sebesar 0,3563 lebih besar dari $\mathrm{I}_{0}$ sebesar $-0,0638$ yang berarti memiliki pola mengelompok (cluster) yang dapat dilihat pada Gambar 2. Sedangkan diperoleh nilai $p$-value sebesar 0,0005 kurang dari $\alpha=5 \%$ yang berarti terjadi autokorelasi lokasi. Dengan demikian, pemodelan harus dilakukan analisis dengan menggunakan pendekatan regresi spasial.

\section{f. Uji Lagrange Multiplier}

Setelah diketahui terdapat efek spasial, selanjutnya dilakukan pengujian Lagrange Multiplier (LM) digunakan untuk memilih model regresi spasial yang sesuai atau yang tepat.

Tabel 5. Pengujian Lagrange Multiplier (LM)

\begin{tabular}{|l|r|c|c|}
\hline & Statistic & df & P-value \\
\hline LM lag (SAR) & 7,2916 & 1,000 & 0,0069 \\
\hline LM error (SEM) & 6,7889 & 1,000 & 0,0092 \\
\hline LM SARMA & 8,1655 & 2,000 & 0,0169 \\
\hline
\end{tabular}

Tabel 5 dapat diketahui bahwa diperoleh $p$-value dari masing-masing model kurang dari $\alpha=5 \%$. Sehingga dapat disimpulkan bahwa terdapat autokorelasi spasial lag, error dan spasial lag dan error. Dengan demikian analisis selanjutnya dilakukan pemodelan regresi spasial dengan pemodelan Spatial Autoregressive Model (SAR), Spatial Error Model (SEM) dan Spatial Autoregressive Moving Average (SARMA).

\section{g. Spatial Autoregressive Model (SAR)}

Setelah diketahui pada uji Lagrange Multiplier (LM) bahwa terdapat autokorelasi spasial lag pada variabel terikat, maka dilakukan analisis pemodelan Spatial Autoregressive Model (SAR) dengan pengujian estimasi parameter untuk mengetahui parameter yang signifikan. Tabel 6 diperoleh hanya terdapat satu parameter yang signifikan yaitu $\widehat{\beta}_{3}$ yang memiliki nilai $t_{\text {hitung }}$ yang lebih besar dari $\mathrm{t}_{(0,025 ; 30)}$ yang berarti tolak $\mathrm{H}_{0}$. Atau dapat dilihat dari $p$-value yang kurang dari $\alpha=5 \%$ sehingga tolak $\mathrm{H}_{0}$. Maka dapat disimpulkan bahwa variabel pekerja sektor informal $\left(\mathrm{X}_{3}\right)$ berpengaruh signifikan terhadap persentase penduduk miskin.

Tabel 6. Estimasi parameter pada model SAR

\begin{tabular}{|l|r|r|r|}
\hline Parameter & \multicolumn{1}{|c|}{ Rho $(\rho)$} & \multicolumn{1}{|c|}{$\hat{\beta}_{0}$} & \multicolumn{1}{c|}{$\hat{\beta}_{1}$} \\
\hline Estimasi & 0,3383 & 133,137 & $-0,0022$ \\
\hline Std. Error & 0,1296 & 79,6554 & 0,1126 \\
\hline $\mathbf{t}_{\text {hitung }}$ & 2,6099 & 1,6714 & $-0,0193$ \\
\hline $\boldsymbol{P}$-value & $0,0091^{*}$ & 0,0946 & 0,9846 \\
\hline
\end{tabular}

\begin{tabular}{|c|c|c|c|}
\hline Parameter & $\widehat{\beta}_{2}$ & $\hat{\beta}_{3}$ & $\widehat{\beta}_{4}$ \\
\hline Estimasi & $-1,3640$ & 0,2357 & $-0,1537$ \\
\hline Std. Error & 0,7932 & 0,0583 & 0,3349 \\
\hline$t_{\text {hitung }}$ & $-1,7196$ & 4,0450 & $-0,4587$ \\
\hline$P$-value & 0,0855 & $5,2 \mathrm{e}-05^{*}$ & 0,6464 \\
\hline Parameter & $\hat{\beta}_{5}$ & $\hat{\beta}_{6}$ & \multirow{5}{*}{$\begin{array}{c}\mathrm{R}^{2} \\
=0,7441 \\
(74,41 \%)\end{array}$} \\
\hline Estimasi & $-0,0616$ & 0,0216 & \\
\hline Std. Error & 0,1134 & 0,0484 & \\
\hline$t_{\text {hitung }}$ & $-0,5437$ & 0,4453 & \\
\hline$P$-value & 0,5866 & 0,6561 & \\
\hline
\end{tabular}

Keterangan: $\mathrm{t}_{(0,025 ; 30)}=2,0423$

*Variabel signifikan

Selain itu juga terdapat efek ketergantungan lokasi pada suatu wilayah dengan wilayah lainnya yang berdekatan $(\rho)$ dengan diperoleh $p$-value kurang dari $\alpha=5 \%$. Koefesien determinasi $\left(\mathrm{R}^{2}\right)$ diperoleh sebesar $74,41 \%$. Hal tersebut menunjukkan bahwa variabel pendidikan yang ditamatkan terakhir SD $\left(\mathrm{X}_{1}\right)$, angka partisipasi sekolah 7-12 tahun $\left(\mathrm{X}_{2}\right)$, pekerja sektor informal $\left(\mathrm{X}_{3}\right)$, tingkat pengangguran terbuka $\left(\mathrm{X}_{4}\right)$, Rumah Tangga menggunakan dinding bambu $\left(\mathrm{X}_{5}\right)$, dan Rumah tangga pengguna sumber air minum tidak layak $\left(\mathrm{X}_{6}\right)$ mampu menjelaskan sebesar $74,41 \%$ terhadap persentase penduduk miskin dan sisanya sebesar 25,59\% dijelaskan oleh variabel lain yang tidak terdapat dalam model. Dari Tabel 6 diperoleh model persamaan sebagai berikut:

$$
\begin{aligned}
\hat{y}_{i}= & 133,1371+0,3383 \sum_{j=1, i \neq j}^{n} W_{i j} Y_{j}- \\
& 0,0022 X_{i 1}-1,3640 X_{i 2}+0,2357 X_{i 3} \\
& -0,1537 X_{i 5}-0,0616 X_{i 5}+0,0215 X_{i 6}
\end{aligned}
$$

\section{h. Uji Asumsi Spatial Autoregressive Model (SAR)}

Pengujian asumsi residual pada model SAR, diperoleh hasil pengujian residual normalitas menggunakan uji Kolmogorov-Smirnov dengan nilai $p$-value sebesar 0,8191 lebih besar dari $\alpha=$ $5 \%$ yang berarti asumsi residual berdistribusi normal terpenuhi. Pengujian heteroskedastisitas dengan uji Breusch-Pagan, diperoleh nilai $p$ value sebesar 0,3862 lebih besar dari $\alpha=5 \%$ yang berarti asumsi residual ragam homogen terpenuhi. Sedangkan pada pengujian autokorelasi menggunakan uji Durbin-Watson, diperoleh nilai DW sebesar 1,2545 dengan du = 1,8641 dan $4-\mathrm{du}=2,1359$, maka nilai DW tidak terletak antara du dan $4-$ du yang berarti terdapat autokorelasi. 


\section{i. Spatial Error Model (SEM)}

Selanjutnya dilakukan analisis regresi dengan menggunakan pemodelan SEM, berikut hasil pengujian estimasi parameter untuk mengetahui parameter yang signifikan.

Tabel 7. Estimasi Parameter pada Model SEM

\begin{tabular}{|l|r|r|r|}
\hline Parameter & $\begin{array}{c}\text { Lambda } \\
(\lambda)\end{array}$ & \multicolumn{1}{c|}{$\widehat{\beta}_{0}$} & \multicolumn{1}{c|}{$\hat{\beta}_{1}$} \\
\hline Estimasi & 0,6342 & 142,633 & $-0,0229$ \\
\hline Std. Error & 0,1321 & 63,3919 & 0,1051 \\
\hline $\mathbf{t}_{\text {hitung }}$ & 4,802 & 2,2500 & $-0,2180$ \\
\hline $\boldsymbol{P}$-value & $1,57 \mathrm{e}-06^{*}$ & $0,0245^{*}$ & 0,8274 \\
\hline
\end{tabular}

\begin{tabular}{|l|r|r|r|}
\hline Parameter & \multicolumn{1}{|c|}{$\hat{\beta}_{2}$} & \multicolumn{1}{|c|}{$\hat{\beta}_{3}$} & \multicolumn{1}{|c|}{$\hat{\beta}_{4}$} \\
\hline Estimasi & $-1,4111$ & 0,2330 & $-0,4631$ \\
\hline Std. Error & 0,6312 & 0,0549 & 0,2779 \\
\hline $\mathbf{t}_{\text {hitung }}$ & $-2,2355$ & 4,2460 & $-1,6663$ \\
\hline $\boldsymbol{P}$-value & $0,0254^{*}$ & $2,2 \mathrm{e}-05^{*}$ & 0,0957 \\
\hline
\end{tabular}

\begin{tabular}{|c|c|c|c|}
\hline Parameter & $\widehat{\beta}_{5}$ & $\widehat{\beta}_{6}$ & \multirow{5}{*}{$\begin{array}{c}\mathrm{R}^{2} \\
=0,7747 \\
(77,47 \%)\end{array}$} \\
\hline Estimasi & $-0,1291$ & 0,1021 & \\
\hline Std. Error & 0,0979 & 0,0476 & \\
\hline$t_{\text {hitung }}$ & $-1,3182$ & 2,1473 & \\
\hline P-value & 0,1875 & $0,0318^{*}$ & \\
\hline
\end{tabular}

Keterangan: $\mathrm{t}_{(0,025 ; 30)}=2,0423$

*Variabel signifikan

Tabel 7 dapat diketahui bahwa terdapat dependensi spasial pada error $(\lambda)$ yang memiliki $p$-value kurang dari $\alpha=5 \%$ yang berarti berpengaruh signifikan, artinya ada keterkaitan persentase penduduk miskin pada suatu wilayah dengan wilayah lainnya yang berdekatan. Selanjutnya parameter yang berpengaruh signifikan, yaitu $\widehat{\beta}_{2}, \widehat{\beta}_{3}$, dan $\widehat{\beta}_{6}$ yang memiliki nilai thitung yang lebih besar dari $\mathrm{t}_{(0,025 ; 30)}$ yang berarti tolak $\mathrm{H}_{0}$. Atau dapat dilihat dari $p$-value masing-masing kurang dari $\alpha=5 \%$ sehingga tolak $\mathrm{H}_{0}$, artinya persentase penduduk miskin di suatu wilayah dipengaruhi oleh angka partisipasi sekolah 7-12 tahun $\left(\mathrm{X}_{2}\right)$, pekerja sektor informal $\left(\mathrm{X}_{3}\right)$, dan Rumah tangga pengguna sumber air minum tidak layak $\left(\mathrm{X}_{6}\right)$. Koefesien determinasi $\left(\mathrm{R}^{2}\right)$ diperoleh sebesar $77,47 \%$. Hal tersebut menunjukkan bahwa variabel pendidikan yang ditamatkan terakhir SD $\left(\mathrm{X}_{1}\right)$, angka partisipasi sekolah 7-12 tahun $\left(X_{2}\right)$, pekerja sektor informal $\left(X_{3}\right)$, tingkat pengangguran terbuka $\left(\mathrm{X}_{4}\right)$, Rumah Tangga menggunakan dinding bambu $\left(\mathrm{X}_{5}\right)$, dan Rumah tangga pengguna sumber air minum tidak layak $\left(\mathrm{X}_{6}\right)$ mampu menjelaskan sebesar $77,47 \%$ terhadap persentase penduduk miskin dan sisanya sebesar $22,53 \%$ dijelaskan oleh variabel lain yang tidak terdapat dalam model. Dari Tabel 7 diperoleh model persamaan sebagai berikut :

$$
\begin{aligned}
\hat{y}_{i}= & 142,633-0,0229 X_{i 1}-1,4111 X_{i 2} \\
& -0,2330 X_{i 3}-0,4631 X_{i 4}+0,1291 X_{i 5} \\
& +0,1021 X_{i 6}+u_{i} \\
u_{i}= & 0,6342 \sum_{j=1, i \neq j}^{n} w_{i j} u_{j}
\end{aligned}
$$

\section{j. Uji Asumsi Spatial Error Model (SEM)}

Pengujian asumsi residual pada model SAR, diperoleh hasil pengujian normalitas menggunakan uji Kolmogorov-Smirnov dengan nilai $p$-value sebesar 0,6124 lebih besar dari $\alpha=5 \%$ yang berarti asumsi residual berdistribusi normal terpenuhi. Pengujian heteroskedastisitas dengan uji BreuschPagan, diperoleh nilai $p$-value sebesar 0,7206 lebih besar dari $\alpha=5 \%$ yang berarti asumsi residual ragam homogen terpenuhi. Sedangkan pada pengujian autokorelasi menggunakan uji DurbinWatson, diperoleh nilai DW sebesar 1,3373 dengan $\mathrm{du}=1,8641$ dan $4-\mathrm{du}=2,1359$, maka nilai DW tidak terletak antara du dan $4-$ du yang berarti terdapat autokorelasi.

\section{k. Spatial Autoregressive Moving Average Model (SARMA)}

Selanjutnya dilakukan analisis regresi spasial menggunakan pemodelan Spatial Autoregressive Moving Average Model (SARMA). Hasil pengujian dapat dilihat pada Tabel 8. Berdasarkan Tabel 8 dapat diketahui bahwa terdapat dependensi spasial pada error $(\lambda)$ dengan diperoleh $p$-value yang kurang dari $\alpha=5 \%$ yang berarti berpengaruh signifikan, artinya ada keterkaitan persentase penduduk miskin pada suatu wilayah dengan wilayah lainnya yang berdekatan. Selanjutnya parameter yang signifikan yaitu $\widehat{\beta}_{2}, \widehat{\beta}_{3}$, dan $\widehat{\beta}_{6}$ yang memiliki nilai thitung yang lebih besar dari $\mathrm{t}_{(0,025 ; 29)}$ yang berarti tolak $\mathrm{H}_{0}$. Atau dapat dilihat dari $p$-value masing-masing kurang dari $\alpha=5 \%$ yang berarti tolak $\mathrm{H}_{0}$. Sehingga variabel angka partisipasi sekolah 7-12 tahun $\left(\mathrm{X}_{2}\right)$ berpengaruh negatif dan signifikan sedangkan pekerja sektor informal $\left(\mathrm{X}_{3}\right)$ dan Rumah tangga pengguna sumber air minum tidak layak $\left(\mathrm{X}_{6}\right)$ berpengaruh positif dan signifikan terhadap persentase penduduk miskin. Koefesien determinasi $\left(\mathrm{R}^{2}\right)$ diperoleh sebesar $77,77 \%$. Hal tersebut menunjukkan bahwa variabel pendidikan yang ditamatkan terakhir $\mathrm{SD}\left(\mathrm{X}_{1}\right)$, angka partisipasi sekolah 7-12 tahun $\left(\mathrm{X}_{2}\right)$, pekerja sektor informal $\left(\mathrm{X}_{3}\right)$, tingkat pengangguran terbuka $\left(\mathrm{X}_{4}\right)$, Rumah Tangga menggunakan dinding bambu $\left(\mathrm{X}_{5}\right)$, dan Rumah tangga pengguna sumber air minum tidak layak $\left(\mathrm{X}_{6}\right)$ mampu menjelaskan sebesar $77,77 \%$ terhadap persentase penduduk miskin dan sisanya 
J Statistika Vol. 11, No. 2,(2018), Hal. 1-8

sebesar $22,23 \%$ dijelaskan oleh variabel lain yang tidak terdapat dalam model.

Tabel 8. Estimasi parameter pada model SARMA

\begin{tabular}{|l|r|r|r|}
\hline Parameter & Rho $(\rho)$ & $\begin{array}{c}\text { Lambda } \\
(\lambda)\end{array}$ & $\widehat{\beta}_{0}$ \\
\hline Estimasi & $-0,1806$ & 0,7423 & 129,1015 \\
\hline Std. Error & 0,2348 & 0,1399 & 60,2534 \\
\hline $\mathbf{t}_{\text {hitung }}$ & $-0,7692$ & 5,3075 & 2,1426 \\
\hline P-value & 0,4418 & $1,1 \mathrm{e}-07 *$ & 1,0321 \\
\hline \multicolumn{4}{|c|}{} \\
\hline Parameter & $\hat{\beta}_{1}$ & $\widehat{\beta}_{2}$ & $\widehat{\beta}_{3}$ \\
\hline Estimasi & 0,0014 & $-1,2515$ & 0,2077 \\
\hline Std. Error & 0,1023 & 0,6082 & 0,0571 \\
\hline $\mathbf{t}_{\text {hitung }}$ & 0,0139 & $-2,0578$ & 3,6388 \\
\hline P-value & 0,9889 & $0,0396^{*}$ & $0,0003^{*}$ \\
\hline \multicolumn{4}{|c|}{} \\
\hline Parameter & $\hat{\beta}_{4}$ & $\widehat{\beta}_{5}$ & $\hat{\beta}_{6}$ \\
\hline Estimasi & $-0,4722$ & $-0,0957$ & 0,1147 \\
\hline Std. Error & 0,2635 & 0,0989 & 0,0467 \\
\hline $\mathbf{t}_{\text {hitung }}$ & $-1,7922$ & $-0,9664$ & 2,4538 \\
\hline P-value & 0,0731 & 0,3339 & $0,0141^{*}$ \\
\hline \multicolumn{4}{|c|}{$\mathrm{R}^{2}=0,7777(77,77 \%)$} \\
\hline
\end{tabular}

Keterangan: $\mathrm{t}_{(0,025 ; 30)}=2,0452$

*Variabel signifikan

Dari Tabel 8 diperoleh model persamaan sebagai berikut :

$$
\begin{aligned}
u_{i}= & 0,7423 \sum_{j=1, i \neq j}^{n} w_{i j} u_{j} \\
\hat{y}_{i}= & 129,1015-0,1806 \sum_{j=1, i \neq j}^{n} W_{i j} Y_{j} \\
& +0,0014 X_{i 1}-1,2515 X_{i 2}-0,2077 X_{i 3} \\
& -0,4722 X_{i 4}-0,0957 X_{i 5}+0,1147 X_{i 6} \\
& +u_{i}
\end{aligned}
$$

1. Uji Asumsi Spatial Autoregressive Moving Average Model (SARMA)

Pengujian asumsi residual pada model SAR, diperoleh hasil pengujian normalitas menggunakan uji Kolmogorov-Smirnov dengan nilai $p$-value sebesar 0,9125 lebih besar dari $\alpha=5 \%$ yang berarti asumsi residual berdistribusi normal terpenuhi. Pengujian heteroskedastisitas dengan uji BreuschPagan, diperoleh nilai $p$-value sebesar 0,6572 lebih besar dari $\alpha=5 \%$ yang berarti asumsi residual ragam homogen terpenuhi. Sedangkan pada pengujian autokorelasi menggunakan uji DurbinWatson, diperoleh nilai DW sebesar 1,2663 dengan $\mathrm{du}=1,8641$ dan $4-\mathrm{du}=2,1359$, maka nilai www.unipasby.ac.id

DW tidak terletak antara du dan $4-$ du yang berarti terdapat autokorelasi.

\section{m. Pemilihan Model Terbaik}

Kriteria pemilihan model terbaik yang digunakan adalah $R$-Square $\left(\mathrm{R}^{2}\right)$ dan Akaike's Information Criterion (AIC). Pemilihan didasarkan pada nilai $\left(\mathrm{R}^{2}\right)$ terbesar dan nialai AIC terkecil.

Tabel 9. Perbandingan Nilai $\mathrm{R}^{2}$ dan AIC pada Model

\begin{tabular}{|l|c|c|}
\hline \multicolumn{1}{|c|}{ Model } & $\mathbf{R}^{\mathbf{2}}$ & AIC \\
\hline $\begin{array}{l}\text { Regresi Linier Berganda } \\
\text { (OLS) }\end{array}$ & $69,06 \%$ & 201,08 \\
\hline $\begin{array}{l}\text { Spatial Autoregressive } \\
\text { Model (SAR) }\end{array}$ & $74,41 \%$ & 195,86 \\
\hline $\begin{array}{l}\text { Spatial Error Model } \\
\text { (SEM) }\end{array}$ & $\mathbf{7 7 , 4 7 \%}$ & $\mathbf{1 9 1 , 0 2}$ \\
\hline $\begin{array}{l}\text { Spatial Autoregressive } \\
\text { Moving Average } \\
\text { (SARMA) }\end{array}$ & $77,77 \%$ & 192,52 \\
\hline
\end{tabular}

Tabel 9 diketahui bahwa nilai AIC terkecil dan $\mathrm{R}^{2}$ terbesar diperoleh pada model Spatial Error Model (SEM) berturut-turut sebesar 191,02 dan 77,47\%. Hal ini menunjukkan bahwa analisis regresi spasial dengan pemodelan Spatial Error Model (SEM) merupakan model terbaik. Berdasarkan pemilihan model terbaik, diperoleh pemodelan SEM dengan pendekatan regresi spasial. Model regresi yang digunakan untuk memodelkan persentase penduduk miskin di Jawa Timur tahun 2015 adalah persamaan (3). Koefesien lambda $(\lambda)$ bertanda positif dan signifikan sebesar 0,6342, maka ada keterkaitan persentase penduduk miskin pada suatu wilayah dengan wilayah lainnya yang berdekatan sebesar yang artinya adanya peningkatan pengaruh sisaan dari wilayah yang mengelilingi suatu kabupaten, maka akan meningkatkan persentase penduduk miskin di suatu kabupaten. Dari persamaan tersebut juga dapat digambarkan dalam suatu wilayah. Misalkan diambil wilayah yang diamati yaitu Kabupaten Sidoarjo. Kabupaten Sidoarjo dengan kode wilayah 15 yang berbatasan dengan Kota Surabaya dengan kode 37, Kabupaten Gresik dengan kode 25, Kabupaten Mojokerto dengan kode 16, dan Kabupaten Pasuruan dengan kode 14. Sehingga persamaan regresi dugaan adalah sebagai berikut : 


$$
\begin{aligned}
\hat{y}_{\text {sidoarjo }}= & 142,633-0,0229 X_{\text {sidoarjo, } 1} \\
& -1,4111 X_{\text {sidoarjo }, 2}-0,2330 X_{\text {sidoarjo, },} \\
& -0,4631 X_{\text {sidoarjo, } 4}+0,1291 X_{\text {sidoarjo, }, 5} \\
& +0,1021 X_{\text {sidoarjo }, 6}+u_{\text {sidoarjo }} \\
u_{\text {sidoarjo }}= & 0,1586_{\text {Kota Surabaya }}+0,1586_{\text {Gresik }} \\
& +0,1586_{\text {Mojo kerto }}+0,1586_{\text {Pasuruan }}
\end{aligned}
$$

Interpretasi dari persamaan diatas, variabel angka partispasi sekolah 7-12 tahun $\left(\mathrm{X}_{2}\right)$ berpengaruh negatif dan signifikan. Jadi, apabila angka partispasi sekolah 7-12 tahun $\left(\mathrm{X}_{2}\right)$ mengalami kenaikan satu satuan dan variabel bebas lainnya konstan, maka variabel persentase penduduk miskin akan mengalami penurunan sebesar 1,4111satuan. Selanjutnya variabel pekerja sektor informal $\left(\mathrm{X}_{3}\right)$ berpengaruh positif dan signifikan. Jadi, jika pekerja sektor informal $\left(\mathrm{X}_{3}\right)$ mengalami kenaikan satu satuan dan variabel bebas lainnya konstan, maka persentase penduduk miskin akan mengalami peningkatan sebesar 0,2330 satuan. Selanjutnya variabel rumah tangga pengguna sumber air minum tidak layak $\left(\mathrm{X}_{6}\right)$ berpengaruh positif dan signifikan. Jadi, jika rumah tangga pengguna sumber air minum tidak layak $\left(\mathrm{X}_{6}\right)$ mengalami kenaikan satu satuan dan variabel bebas lainnya konstan, maka persentase penduduk miskin akan mengalami peningkatan sebesar 0,1021 . Selanjutnya persentase penduduk miskin di Kabupaten Sidoarjo juga dipengaruhi oleh tetangganya yaitu Kota Surabaya, Kabupaten Gresik, Kabupaten Mojokerto, dan Kabupaten Pasuruan masing-masing sebesar 0,1586 satuan.

\section{KESIMPULAN DAN SARAN}

Berdasarkan hasil analisis dan pembahasan didapatkan kesimpulan bahwa pola persebaran persentase kemiskinan kabupaten dan kota di Jawa Timur terbagi menjadi enam kelompok dengan zona prioritas pertama $(>=35 \%)$ tidak ada kabupaten/kota yang masuk dalam kelompok ini. Zona prioritas kedua $(25-<35 \%)$ hanya terjadi pada kabupaten Sampang yang memiliki persentase kemiskinan tinggi sebesar $25,69 \%$. Zona prioritas ketiga (20 $<25 \%)$ terjadi di tiga kabupaten. Zona prioritas keempat $(15-<20 \%)$ terjadi di enam kabupaten. Zona prioritas kelima $(10-<15 \%)$ terjadi di lima belas kabupaten. Sedangkan pada zona prioritas keenam $(0-<10 \%)$ terdapat tiga belas kabupaten/kota dengan kota malang menduduki persentase kemiskinan paling rendah sebesar $4,60 \%$. Sedangkan pemodelan dengan pendekatan regresi spasial diperoleh model terbaik yaitu Spatial Error Model (SEM) dengan pembobot Queen Contiguity diperoleh nilai AIC dan $\mathrm{R}^{2}$ berturut-turut sebesar
191,02 dan 77,47\%. Model SEM yang terbentuk sebagai berikut:

$\hat{\mathrm{y}}_{\mathrm{i}}=142,633-0,0229 \mathrm{X}_{\mathrm{i} 1}-1,4111 \mathrm{X}_{\mathrm{i} 2}+$

$0,2330 X_{i 3}-0,4631 X_{i 4}-0,1291 X_{i 5}+$

$0,1021 X_{i 6}+u_{i}$

$u_{i}=0,6342 \sum_{j=1, i \neq j}^{n} w_{i j} u_{j}$

Berdasarkan hasil penelitian yang diperoleh, maka ada beberapa saran yang dapat dikemukakan yaitu sebagai berikut:

1. Pada penelitian ini membahas model regresi spasial hanya pada data cross section dengan kasus kemiskinan di kabupaten/kota Jawa Timur, diharapkan pada penelitian selanjutnya dapat dikembangkan dengan menggunakan data panel.

2. Pengujian asumsi residual independen pada penelitian ini tidak terpenuhi, diharapkan dalam penelitian selanjutnya dimungkinkan ada metode lain yang dapat mengatasi asumsi independen yang terlanggar.

\section{DAFTAR PUSTAKA}

Anselin. 1988. Spatial Econometrics: Methods and Models. Dordrecht: Academis Publisher.

Badan Ketahanan Pangan. 2018. Laporan Tahunan Badan Ketahanan Pangan Tahun 2017. Kepala Badan Ketahanan Pangan: Jakarta.

Badan Pusat Statistik. 2015. Data dan Informasi Kemiskinan Kabupaten/Kota, BPS: Jakarta.

Drapper, N \& Smith, H.. 1992. Analisis Regresi Terapan Edisi Kedua. Penerjemah: Bambang Sumantri. Jakarta: Gramedia Pustaka Umum.

LeSage. J.P.. 2009. Introduction to Spatial Econometrics, CRC Press. Taylor and Press.

Rahmawati. R. dkk. 2015. Analisis Spasial Pengaruh Tingkat Pengangguran Terhadap Kemiskinan di Indonesia dengan Studi Kasus Provinsi Jawa Tengah, Media Statistika Vol. 8, No. 1, Universitas Diponegoro: Semarang. 